CZASOPISMO INŻYNIERII LĄDOWEJ, ŚRODOWISKA I ARCHITEKTURY JOURNAL OF CIVIL ENGINEERING, ENVIRONMENT AND ARCHITECTURE

JCEEA, t. XXXIV, z. 64 (3/II/17), lipiec-wrzesień 2017, s. 181-192, DOI:10.7862/rb.2017.163

Lech LICHOLAI

\title{
MOŻLIWOŚCI ZASTOSOWANIA ODNAWIALNYCH ŹRÓDEŁ ENERGII W MIASTACH PRZYSZLOŚCI
}

\begin{abstract}
Współczesne miasta wypełniają różne funkcje. Przeważnie, miasta skupiają w swoim obszarze wiele przenikających się zadań funkcjonalnych, wynikających $\mathrm{z}$ ich użytkowania. Istnieją także miasta o dedykowanych funkcjach (administracyjne, przemysłowe, transportowe, handlowe, edukacyjne, turystyczne, wypoczynkowe, uzdrowiskowe, kultu religijnego i inne) kształtowanych na przestrzeni lat w sposób przemyślany. Obecny rozwój cywilizacyjny powoduje rozrost infrastruktury miejskiej, a także zwiększanie ludności miast, zarówno przebywających w nich tymczasowo lub na stałe. Miasta różnią się wielkością, usytuowaniem geograficznym i możliwością wpływania na rozwój społeczny lub gospodarczy. Wszystkie skupiska miejskie potrzebują dostarczania do nich różnych postaci energii dla normalnego funkcjonowania. Pojedyncze i zespolone funkcje miastotwórcze charakteryzują się znacznymi potrzebami energetycznymi. W większości, miasta wykorzystują na swoje potrzeby energetyczne konwencjonalne źródła energii. Zmniejszające się zasoby tych nośników energetycznych, troska o czystość środowiska, a także względy ekonomiczne powodują zainteresowanie niekonwencjonalnymi źródłami energii, które możliwe są do wypełniania energetycznych, miejskich potrzeb. Te potrzeby energetyczne mogą być realizowane w niekonwencjonalnych technologiach w oparciu o różne energie; promieniowania słonecznego, wiatru, wody, wnętrza ziemi i innych. Zastosowanie różnorodnych niekonwencjonalnych rozwiązań będzie pomocne w zaspokojeniu potrzeb energetycznych miast przyszłości. Równocześnie należy rozważyć zalety, wady, korzyści i zagrożenia, aby miasta przyszłości były przyjazne dla ludzi w wypełnianiu energetycznych zadań wynikających z realizowania bieżących i przyszłych funkcji miejskich.
\end{abstract}

Słowa kluczowe: rozwój zrównoważony, infrastruktura miejska, potrzeby energetyczne, odnawialne źródła energii

\footnotetext{
${ }^{1}$ Lech Lichołai, Politechnika Rzeszowska, Zakład Budownictwa Ogólnego, al. Powstańców Warszawy 12, 35-959 Rzeszów; tel.: 17865 1327; e-mail: Lech.Licholai@prz.edu.pl
} 


\section{Wprowadzenie}

Miasta odgrywają ważną rolę w życiu społecznym. W aglomeracjach miejskich, w ujęciu globalnym mieszka bardzo dużo ludzi, ma to wpływ na funkcjonowanie i rozwój gospodarczy poszczególnych państw. Obecnie kulę ziemską zamieszkuje prawie 7,5 mld ludzi. Sięgając wstecz do danych liczbowych obserwuje się systematyczny wzrost liczby ludności w skali globalnej. Na początku XX wieku kulę ziemską zamieszkiwało 1,6 mld ludzi, w połowie wieku 2,5 mld, a przy końcu poprzedniego wieku już 6 mld. Według danych Organizacji Narodów Zjednoczonych przewiduje się, że w 2030 roku na kuli ziemskiej będzie mieszkać około 8,5 mld ludzi, w 2050 roku około 9,7 mld, a w 2100 roku ponad 11 mld ludzi. Jednocześnie prognozuje się, że coraz więcej ludzi będzie mieszkać w miastach. W 1950 roku miasta zamieszkiwało $30 \%$ populacji, w czasach obecnych jest to $55 \%$, a w 2050 ponad $65 \%$ ludzi będzie mieszkała w miastach (rys. 1). Taka sytuacja wynika $z$ szybkiego tempa urbanizacji i wskazuje na ważne zagadnienie jakim jest funkcjonowanie, obraz przestrzenny i potrzeby miast przyszłości w bliższej i dalszej perspektywie czasowej $[1,2]$. Tym bardziej jest to istotne, ponieważ zamieszkująca obecnie w miastach ludność jest zaangażowana w około 70-80\% globalną działalność gospodarczą, odpowiada za $80 \%$ zużycie różnych form energii i ma udział w $80 \%$ emisji gazów cieplarnianych.

Na przestrzeni dziejów, ludzie wznoszą wiele obiektów budowlanych, charakteryzujących się określonymi stylami oraz przestrzennymi i funkcjonalnymi rozwiązaniami. Są one świadectwem cywilizacyjnym konkretnych czasów i przenoszą dziedzictwo kulturowe na następne lata. Można przytoczyć wiele przykładów współczesnej miejskiej zabudowy, która stanowiąc przestrzeń urbanistyczną jest charakterystycznym obrazem rozpatrywanym $\mathrm{w}$ zagadnieniach eksploatacyjnych, użytkowych jak również w kontekście zachowania wartości kulturowych i przekazywania na kolejne lata ich walorów kompozycyjnych (rys. 2-3).

Zabudowa architektoniczna posiada także wartości społeczne, jest również turystycznym celem wynikającym z potrzeby poznawania cywilizacyjnych osiągnięć miejskich struktur przestrzennych. Obiekty te potrzebują obecnie i będą potrzebować w przyszłości do swojego funkcjonowania zasilania energetycznego [3]. Jednym z zadań, jakże istotnych dla miast przyszłości będzie niezawodne dostarczanie do nich potrzebnych postaci energii. 


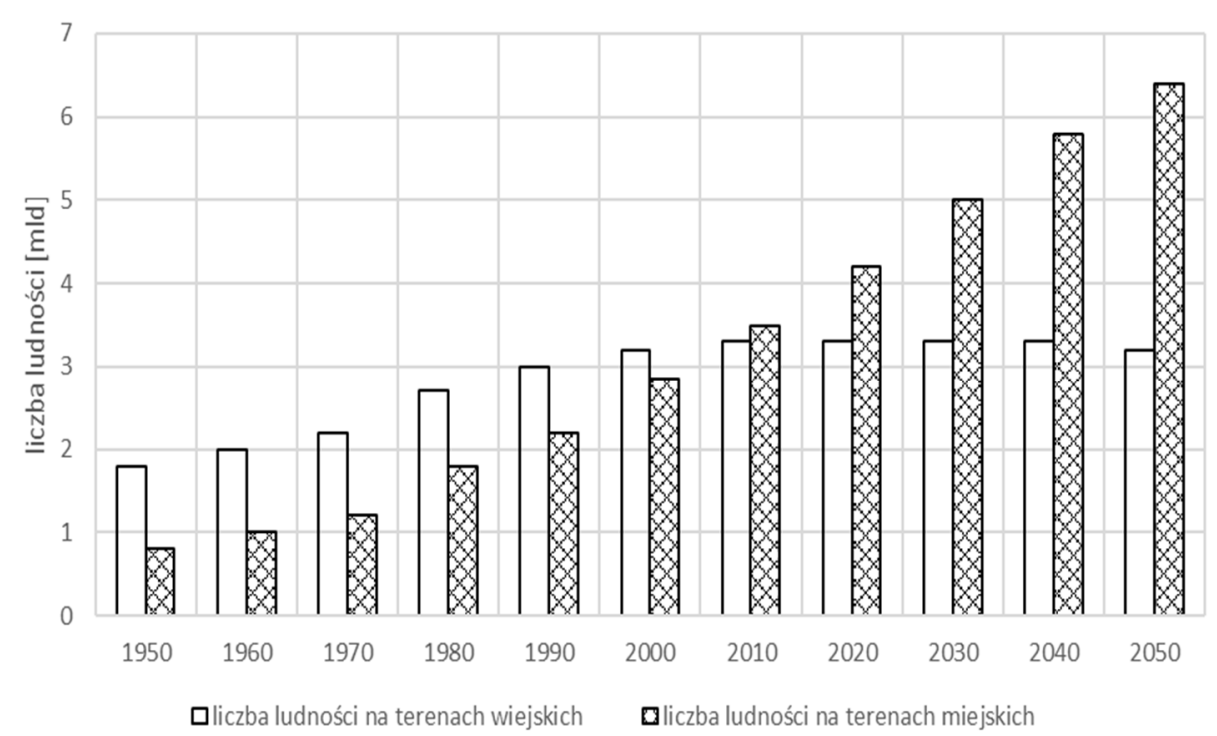

Rys. 1. Liczba ludności w skali globalnej w latach 1950 - 2050. Rys.1. opr. autor

Fig. 1. Population on a global scale in 1950 - 2050, authors' study

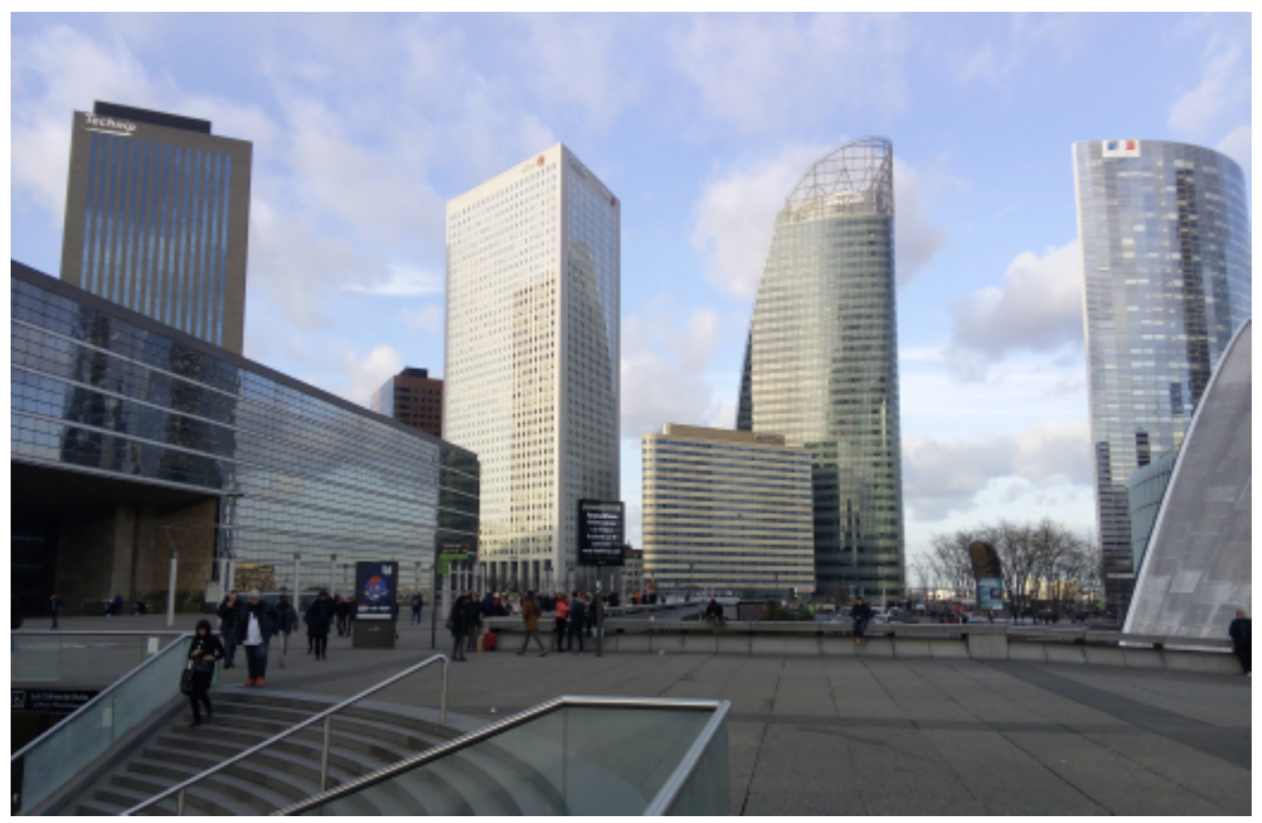

Rys. 2. Zabudowa miejska Paryża. Fot. autor

Fig. 2. City buildings in Paris, authors' photo 


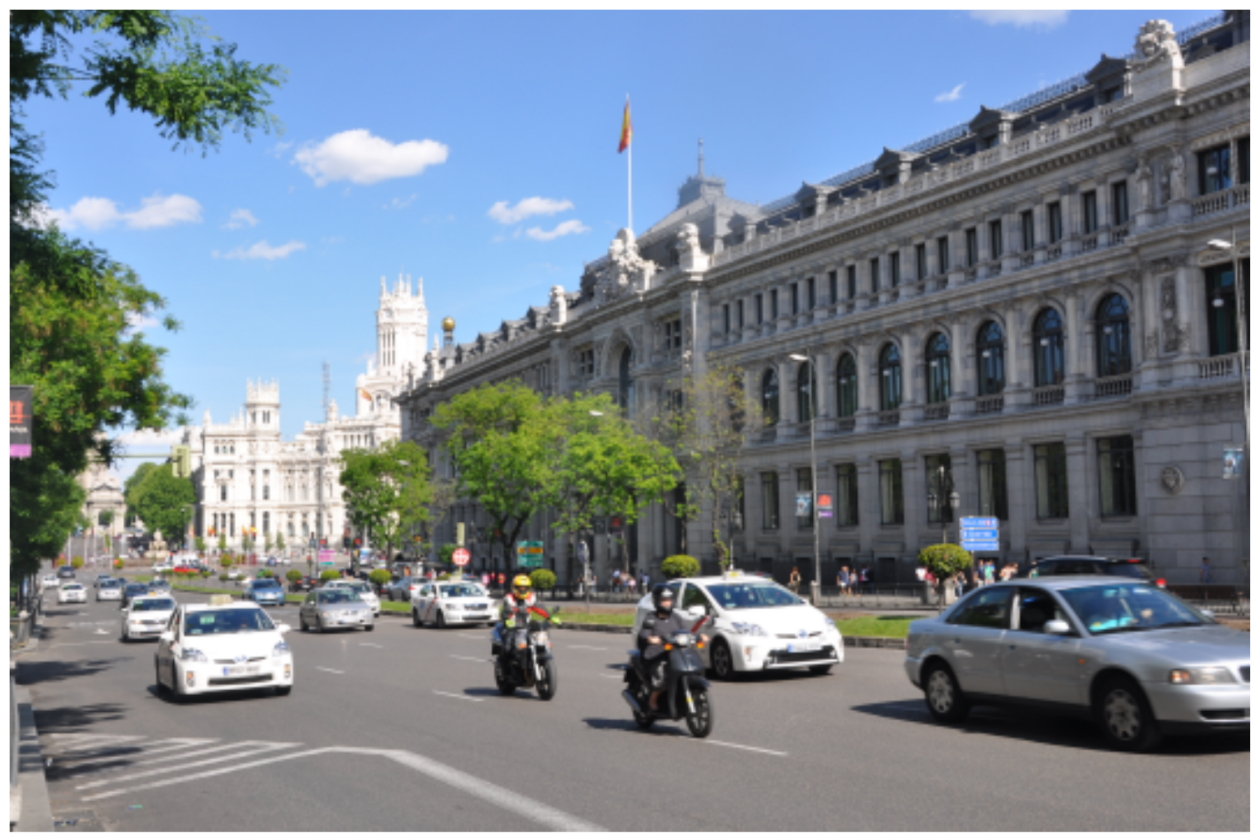

Rys. 3. Zabudowa miejska Madrytu. Fot. autor

Fig. 3. City buildings in Madrid, authors' photo

\section{Zagadnienia energetyczne $\mathrm{w}$ miastach}

We współczesnych czasach różne formy energii są niezbędne ludziom dla zaspokajania społeczno-bytowych potrzeb, realizowanych w obiektach architektoniczno-budowlanych o różnym przeznaczeniu. Istotnym zagadnieniem jest zapewnienie optymalnych warunków dla użytkowników obiektów w okresie ich eksploatowania. Działalność budowlana ma ścisły związek z zagadnieniami zrównoważonego rozwoju, ponieważ jej wpływ na środowisko jest znaczący. Zrównoważony rozwój w budownictwie jest ważnym cywilizacyjnym procesem i zestawem racjonalnych działań mającym na celu zaspokojenie potrzeb obecnego pokolenia $\mathrm{w}$ sposób umożliwiający realizację tych samych potrzeb następnym pokoleniom. Dla miast oznacza to stworzenie przyjaznych i godnych warunków życia obecnym mieszkańcom, zważając, aby nie powodować zagrożeń przyszłymi problemami dla następnych mieszkańców i otoczenia. Obecnie, ponad $40 \%$ globalnej produkcji różnych form energii zużywane jest $\mathrm{w}$ budownictwie, około 35\% światowej emisji gazów cieplarnianych pochodzi z funkcjonowania obiektów budowlanych, a około 50\% masy przetwarzanych w skali globalnej materiałów przypada na aktywność budowlaną. W cyklu życia obiektu budynek zużywa energię w postaci wbudowanej, eksploatacyjnej i przetworzenia. Energia wbudowana jest zgromadzoną energią w budynku w formie zużytej energii potrzebnej do wyprodukowania $\mathrm{i}$ transportu materiałów budowlanych 
oraz wszelkiej postaci energii potrzebnej do zrealizowania obiektu. Energia eksploatacyjna jest wymagana do kompleksowego, energetycznego użytkowania budynku na potrzeby oświetlenia, ogrzewania, chłodzenia, wentylacji, przygotowania posiłków. Energia przetworzenia jest energią zużywaną w trakcie remontów, napraw, modernizacji, a także zakończenia użytkowania obiektu i na potrzeby zagospodarowania odpadów. Im bardziej miasto posiada zalety związane ze zrównoważonym rozwojem tym wyższy w nim poziom życia i dobrobyt oraz tym niższy szkodliwy wpływ na klimat i środowisko. Ważnym, współczesnym zagadnieniem jest zapewnienie bezawaryjnego dostarczania różnych form energii, przede wszystkim elektrycznej do odbiorców końcowych [4]. Niestety, awarie większe lub mniejsze mogą się pojawiać. W szczególności duże awarie w sposób wyjątkowo niepożądany wpływają na bieg codziennego życia. Duża awaria zasilania w prąd elektryczny, która wystąpiła w USA w 2003 roku dotknęła ponad 50 milionów ludzi. Prace związane $\mathrm{z}$ usuwaniem awarii trwały kilka dni, a brak zasilania spowodował nagłe wyhamowanie powszedniego życia, jak również wstrzymanie toczących się procesów gospodarczych, odnotowano straty finansowe sięgające kilku miliardów dolarów. Takie doświadczenia skłaniają do zwiększenia uwagi w technicznym obszarze skutecznego i pewnego zapewnienia dostarczania różnych postaci energii do współczesnych i przyszłych miast.

\section{Rozwiązania energetyki odnawialnej na potrzeby funkcjonowania miast}

Zmniejszające się zasoby powszechnie stosowanych surowców energetycznych, troska o ograniczenie zanieczyszczania środowiska, a także zagadnienia ekonomiczne skłaniają współczesne społeczeństwo do zainteresowania wykorzystaniem niekonwencjonalnych rozwiązań technologicznych w celu spełnienia energetycznych, miejskich potrzeb. Źródła energii można podzielić na nieodnawialne $\mathrm{i}$ odnawialne. Nieodnawialne źródła energii to takie, których zasoby wyczerpują się systematycznie w związku z ich eksploatacją, a których rezerwy są ograniczone. Do tych źródeł zaliczamy: węgiel w różnych energetycznych postaciach, ropę naftową, gaz ziemny, a także uran wykorzystywany na potrzeby energetyki jądrowej. Te kopalne paliwa są obecnie podstawowymi globalnymi surowcami energetycznymi. Energetyczne źródła odnawialne to takie, których zasoby są praktycznie niewyczerpywalne i są stale zasilane przez energię promieniowania słonecznego. Do zestawu tych źródeł zaliczamy przede wszystkim energię słoneczną, która dociera do kuli ziemskiej, a także energię wiatru, rzek i innych zasobów wodnych, oraz energię geotermalną. Potencjał energetyczny zasobów odnawialnych jest ogromny. Mogą one podołać potrzebom energetycznym w skali globalnej. Problemem są zagadnienia dotyczące magazynowania pozyskanej postaci energii. Współczesne rozwiązania technologiczne są w tym zakresie niewystarczalne. Prowadzane są liczne badania naukowe dotyczące 
poprawienia skuteczności magazynowania różnych form energii pozyskanych z odnawialnych źródeł energetycznych. O ile zagadnienia związane z wytwarzaniem różnych postaci energii z zasobów odnawialnych są współcześnie na zadawalającym, akceptowalnym technicznym poziomie, to kompleksowe podniesienie efektywności energetycznych systemów, działających w oparciu o odnawialne źródła energii wzrośnie wraz z zastosowaniem skutecznych sposobów magazynowania różnych form energii pozyskiwanych z odnawialnych źródeł.

Najważniejszym wyzwaniem energetycznym współczesnego rozwoju cywilizacyjnego jest zapewnienie dostarczania energii elektrycznej na potrzeby społeczno-gospodarczego funkcjonowania. W oczywisty sposób wszelkie aglomeracje miejskie do wypełniania swoich zadań potrzebują energii elektrycznej. Wytwarzanie energii elektrycznej odbywa się przy wykorzystaniu różnych technologii. Współczesnymi sposobami wytwarzania energii elektrycznej są technologie wykorzystujące spalanie paliw kopalnych w elektrowniach konwencjonalnych lub paliw jądrowych w elektrowniach jądrowych. Zarówno elektrownie konwencjonalne jak i jądrowe to duże obiekty budowlane, które włączone są do sieci elektroenergetycznych przesyłających prąd na znaczne odległości. Obok tych technologii coraz powszechniej pojawiają się elektrownie wykorzystujące energię z źródeł odnawialnych (rys. 4-5). Na potrzeby produkcji prądu elektrycznego wykorzystuje się najczęściej energię promieniowania słonecznego, wiatru i wody.

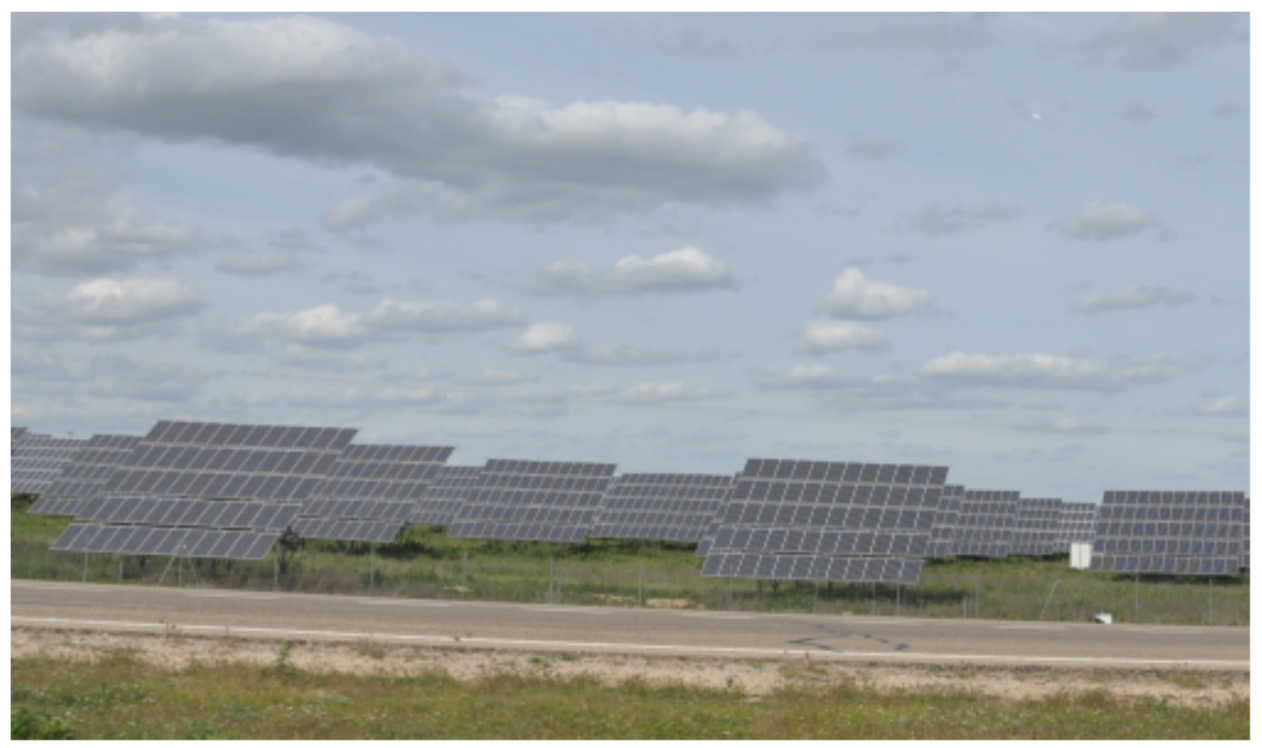

Rys. 4. Systemy fotowoltaiczne. Fot. autor

Fig. 4. Photovoltaic systems, authors' photo 


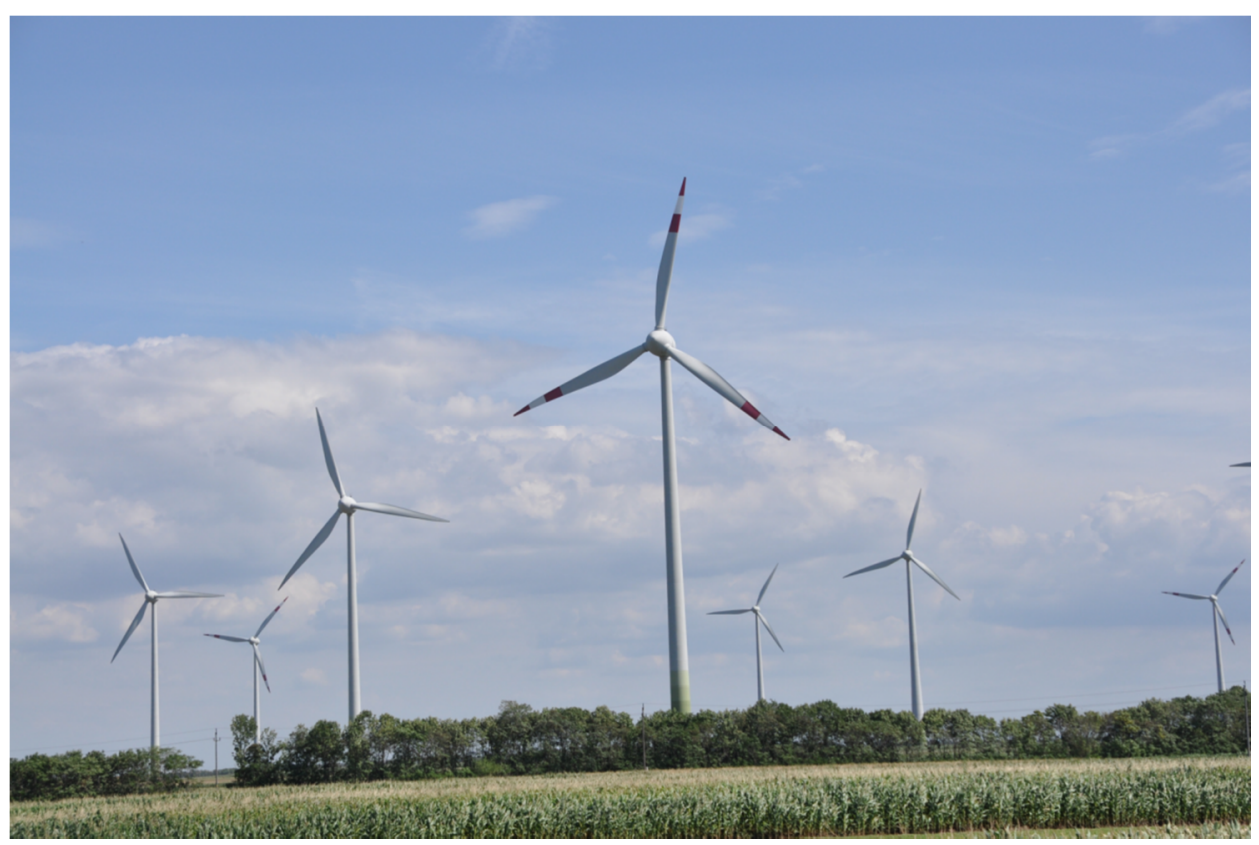

Rys. 5. Turbiny wiatrowe. Fot. autor

Fig. 5. Wind turbines, authors' photo

Systemy fotowoltaiczne działają w oparciu o fizyczne zjawisko powstawania siły elektromotorycznej, możliwej do wystąpienia w materiale stałym pod wpływem promieniowania świetlnego. Ten obszar fotowoltaicznych rozwiązań wykorzystujących energię promieniowania słonecznego na cele użytkowe jest dynamicznie rozwijany. Prowadzone są prace naukowe, a także wdrożeniowe mające na celu poprawę sprawności energetycznej pojedynczych ogniw fotowoltaicznych, co przełoży się na zwiększenie wydajności modułów i systemów wytwarzających energię elektryczną. Turbiny wiatrowe są urządzeniami generującymi prąd elektryczny przy pomocy zamiany energii kinetycznej wiatru na energię mechaniczną, która w postaci ruchu obrotowego wirnika napędza generator wytwarzający prąd elektryczny. Zestaw turbin wiatrowych to najważniejsze składowe elektrowni wiatrowych. Elektrownie wiatrowe lokalizowane są na lądzie lub na otwartych akwenach morskich. Do zalet morskich elektrowni wiatrowych zalicza się stabilniejsze, energetyczne warunki wiatrowe, możliwość wykorzystania większej powierzchni pod lokalizację turbin, mniejszą ingerencję w przestrzeń krajobrazową w aspekcie wizualnym i przyrodniczym. Elektrownie wodne wykorzystują potencjał energetyczny płynących rzek i wytwarzają energię elektryczną $\mathrm{w}$ turbinach wprawianych $\mathrm{w}$ ruch obrotowy przy pomocy przemieszczanych we wnętrzu zapory strumieni wody. Powstające prze zaporach wodnych zbiorniki retencyjne przyczyniają się do regulacji dynamiki rzek, 
zmniejszają zagrożenie powodziowe, a także stwarzają możliwości powstania infrastruktury turystycznej i wypoczynkowej w pobliżu linii brzegowej tych zbiorników.

Zarówno elektrownie fotowoltaiczne, wiatrowe czy wodne mogą występować jako duże zakłady wytwarzające energię elektryczną na znaczne potrzeby, w tym na potrzeby aglomeracji miejskich, jak również jako mniejsze obiekty przeznaczone do wykorzystania na potrzeby pojedynczego budynku lub grupy budynków, czy też osiedla. To jest ich przewaga w stosunku do elektrowni konwencjonalnych czy jądrowych, które realizowane są wyłącznie jako duże inwestycje energetyczne, z których prąd przesyłany jest rozległymi sieciami elektroenergetycznymi (RSE) na pokaźne odległości.

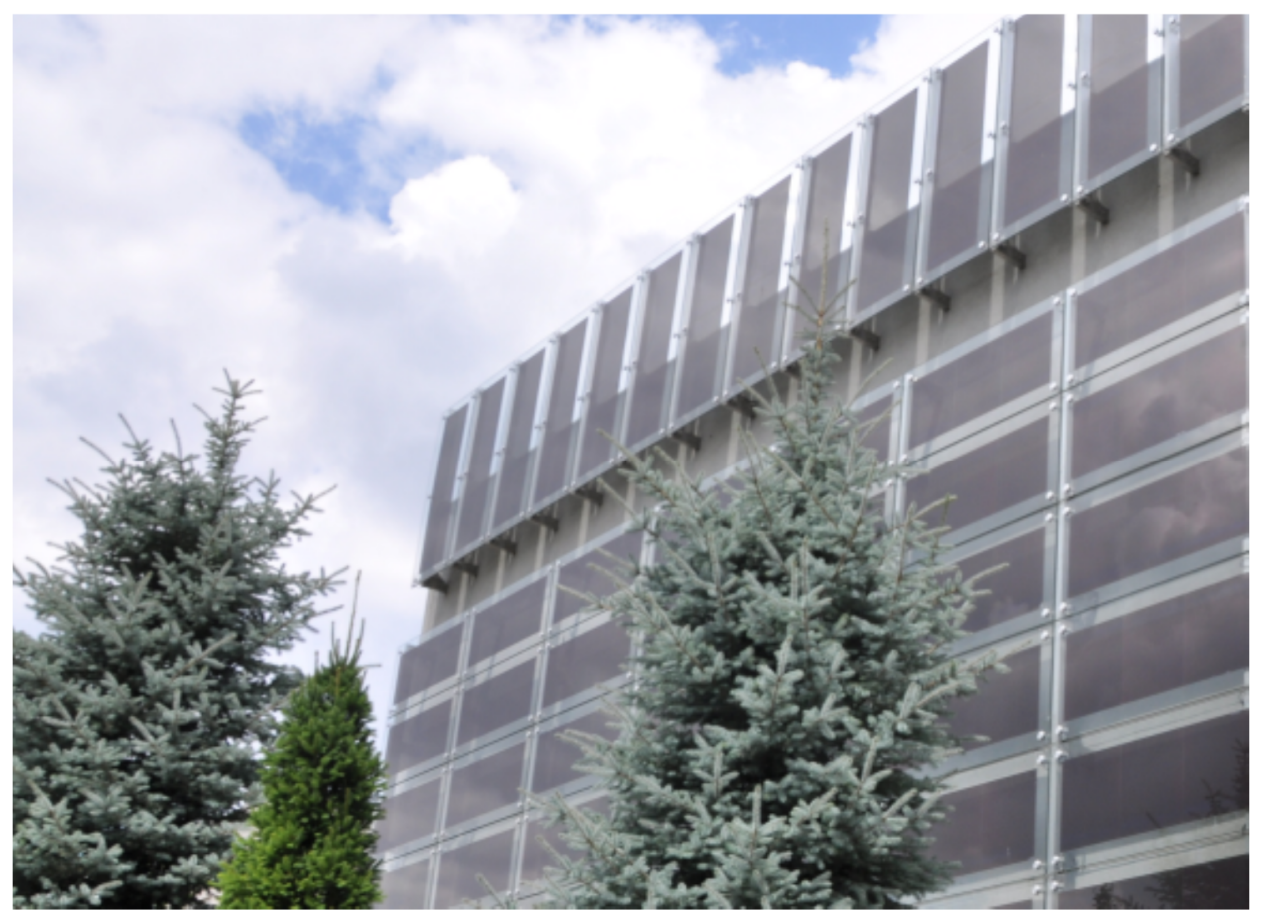

Rys. 6. Fasada z elementami fotowoltaicznymi. Fot. autor

Fig. 6. Facade with photovoltaic elements, authors' photo

Techniczne układy strukturalne przesyłające energię elektryczną powinny być niezawodne, gdyż ich awarie powodują natychmiastowe negatywne oddziaływania dla docelowych odbiorców prądu elektrycznego. Awarie wynikają najczęściej z przeciążeń lub uszkodzeń tych linii. Zwiększające się zapotrzebowanie na energię elektryczną przez istniejących, a także nowych odbiorców, powo- 
duje wzrost ryzyka występowania awarii sieci przesyłowych. Aby przeciwdziałać temu zagrożeniu, rozsądnym wydaje się coraz liczniejsze powstawanie nowych przesyłowych sieci, działających w układach rozproszonych. Tak organizowane, małe sieci elektroenergetyczne (MSE), mogą jako mikro sieci funkcjonować samodzielnie lub wspierać główne na danym obszarze sieci przesyłowe. Te lokalne sieci mogą służyć do przesyłania energii elektrycznej z elektrowni wytwarzających prąd w oparciu o wykorzystywanie odnawialnych źródeł energii. Mogą one obsługiwać budynki lub zespoły budynków o konkretnym przeznaczeniu (mieszkalnym, przemysłowym, służby zdrowia itp.) zlokalizowanych w określonym miejscu, osiedlu, dzielnicy. Innym, istniejącym obecnie i rozwijającym się rozwiązaniem w obszarze energetycznego funkcjonowania obiektów budowlanych są autonomiczne systemy elektroenergetyczne (ASE). Istotą ich działania jest indywidualne wyposażenie obiektu inżynierskiego, budynku lub obiektu małej architektury w systemy wytwarzające prąd elektryczny z przeznaczeniem na potrzeby tego konkretnego obiektu (rys. 6-8).

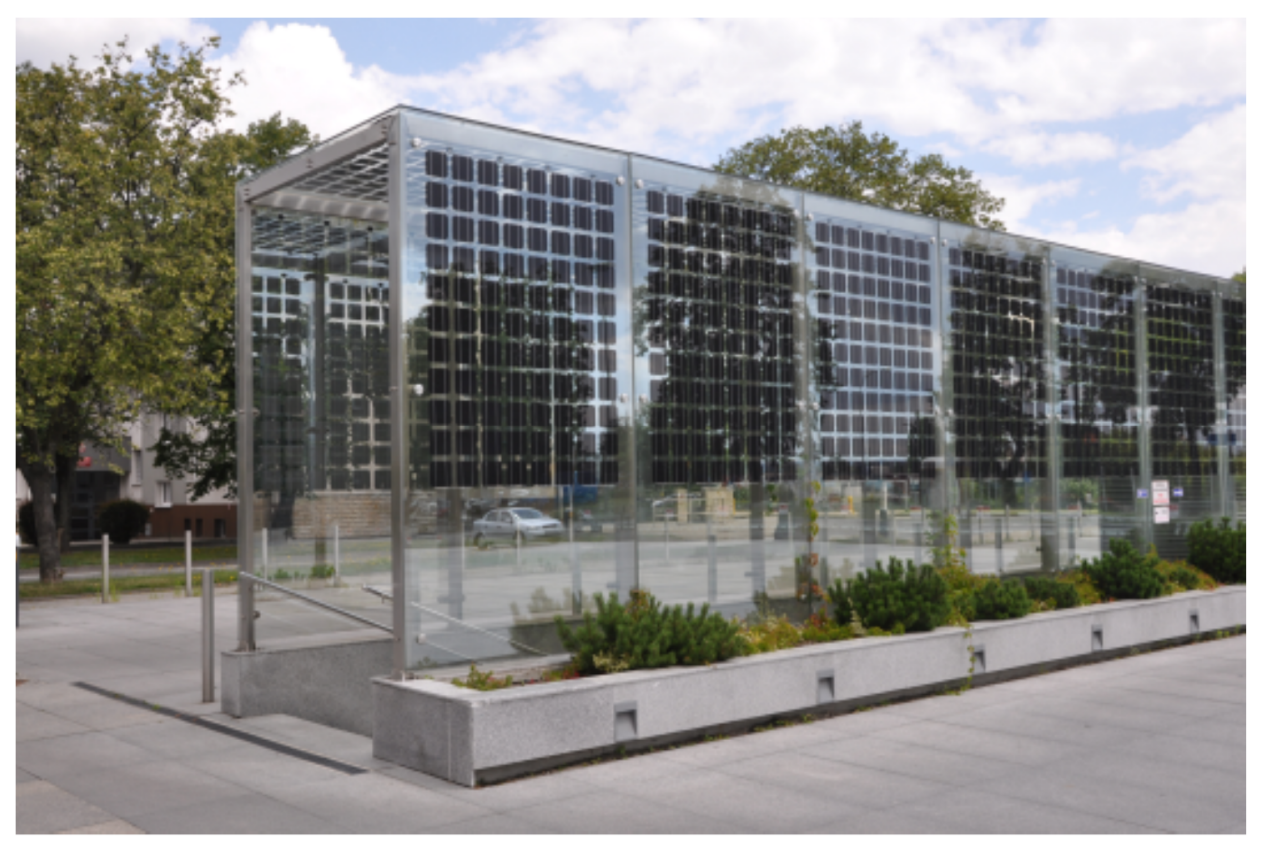

Rys. 7. Elementy fotowoltaiczne w małej architekturze. Fot. autor

Fig. 7. Photovoltaic elements in a small architecture, authors' photo

Te obiecujące rozwiązania mogą być stosowane w nowo powstających obiektach, w postaci wkomponowywania już na etapie projektowania i wykonawstwa materiałów posiadających właściwości fotowoltaiczne (szyby, fasady 
ścienne, pokrycia dachowe). Również obiekty istniejące mogą być doposażane w elementy fotowoltaiczne.

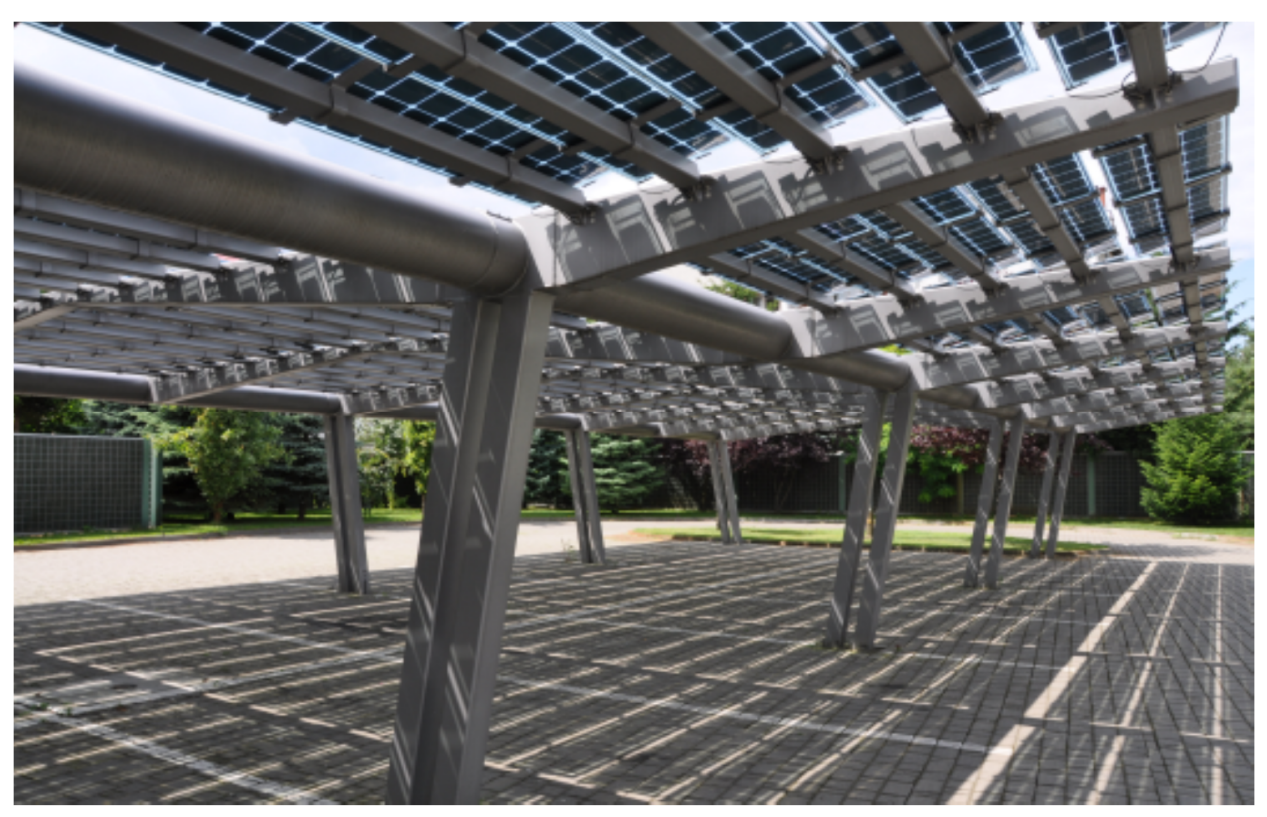

Rys. 8. Elementy fotowoltaiczne w małej architekturze. Fot. autor

Fig. 8. Photovoltaic elements in a small architecture, authors' photo

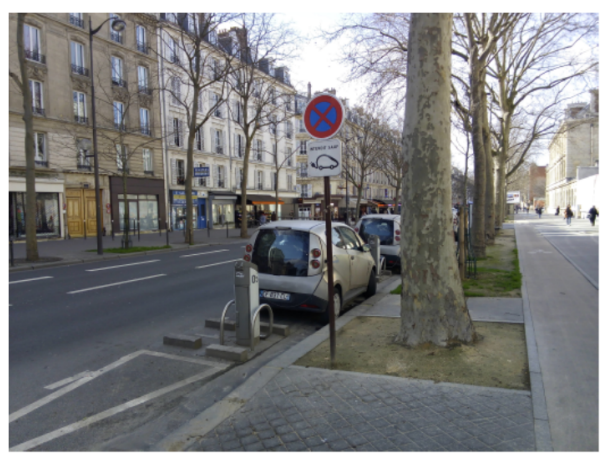

Rys. 9. Punkt ładowania energii elektrycznej. Fot. autor

Fig. 9. Electricity charging point, authors' photo

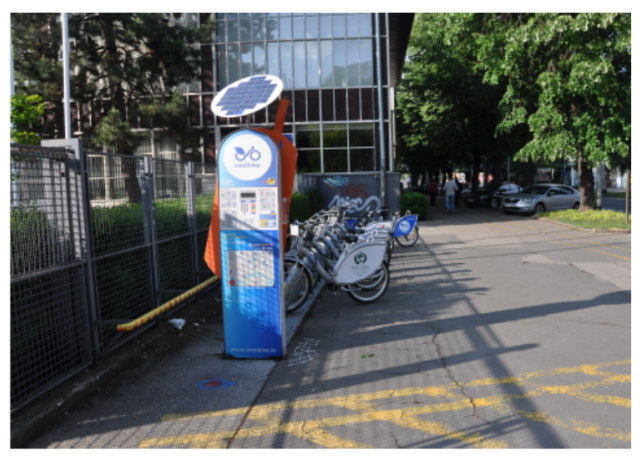

Rys. 10. Fotowoltaika w urządzeniach miejskich. Fot. autor

Fig. 10. Photovoltaics in urban equipment 
Ważnym zagadnieniem $\mathrm{w}$ miastach przyszłości będzie zorganizowanie transportu miejskiego [5]. Coraz powszechniej spotyka się już elektryczne pojazdy, w wielu miastach znajdują się punkty do ładowania energii elektrycznej w pojazdach. Ponadto wydaje się, że systemy fotowoltaiczne będą dostarczały energię elektryczną do różnych urządzeń wymagającej tej energii do swojego funkcjonowania (rys. 9-10).

\section{Podsumowanie}

Potrzeby energetyczne w skali globalnej wzrastają, ma to związek ze zwiększającą się liczbą ludności, a także wynika z postępu społecznego i technologicznego. Trudno jest przewidywać dokładne rozwiązania energetyczne przyszłych aglomeracji miejskich, jednak wydaje się, że odnawialne źródła energii mogą być jedną z podstaw rozwiązywania potrzeb energetycznych miast przyszłości. Aby to było skuteczne, oczekuje się postępu w zwiększeniu efektywności technologii helioenergetycznych, w tym w zakresie magazynowania różnorodnych postaci energii. Dla zapewnienia zrównoważonego rozwoju miast przyszłości potrzebna jest harmonijna współpraca specjalistów z różnych obszarów zawodowych. Bardzo ważną rolę odgrywać będą projektanci przyszłych aglomeracji miejskich, specjaliści w zakresie ochrony zabytków, zrównoważonych technologii infrastrukturalnych, ekonomiści, przyrodnicy, a także inni eksperci i profesjonaliści. Rozważania w tym obszarze tematycznym powinny być kontynuowane $z$ uwagi na ważność zagadnień dotyczących obrazu i funkcjonowania miast przyszłości.

\section{Literatura}

[1] Bibri S.E., Krogstie J.: Smart sustainable cities of the future: An extensive interdiscipzlinary literature review, Sustainable Cities and Society 31 (2017) 183-212

[2] Saaty T.L, Sagir M.: Choosing the best city of the future, Journal of Urban Management 4 (2015) 3-23

[3] Lichołai, L., Gosztyła, M. Aplikacja systemów helioenergetycznych w zabytkową strukturę obiektów kościelnych, Zeszyty Naukowe Politechniki Rzeszowskiej. Budownictwo i Inżynieria Środowiska, 2008, z. 47 [252] 243-248

[4] Sarwar S., Chen W., Waheed R.: Electricity consumption, oil price and economic growth: Global perspective, Renewable and Sustainable Energy Reviews 76 (2017) 9-18

[5] Wegener M.: The future of mobility in cities: Challenges for urban modeling, Transport Policy 29 (2013) 275-282 


\section{POSSIBILITIES OF APPLICATION OF RENEWABLE ENERGY SOURCES IN CITIES OF THE FUTURE}

\section{S u m m a r y}

Modern cities perform different functions. The dominant function in different cities varies, however more often, they fulfill variety of tasks, which is a result of its' utility. One the other hand, they can serve as a single purpose ( such as administrative, industry, transport, trade, education, recreation and touristic, or associated to religious cult) and were located on a predetermined plan. Current stage of civilization development cause enlargement of urban areas followed by increase in both permanent and temporary population. Size, geographical location and possibility in influence on social or economic development vary among individual cities. However, all of them need different forms of energy supply in order to perform functions essentials for its inhabitants. Both single and complex urbanocentric functions are associated with noticeable energy needs. Most of the necessary power we capture using conventional energy source. But decreasing amount of conventional energy carriers, caring for natural environment and economic reason led to increased attention to unconventional energy sources, which could supply cities in energy. Cities' energy needs could be perform using variety of unconventional sources, based on solar, wind, water and geothermal energy. Utility of renewable energy sources would help to meet the growing demand for energy in the future cities. Simultaneously, it is necessary to take into consideration both pros and cons associated with renewable energy sources in order to construct future cities, which will be inhabitants-friendly.

Keywords: sustainable development, urban infrastructure, energy needs, renewable energy sources

Przestano do redakcji: 09.06.2017 r.

Przyjęto do druku: 01.09.2017 r. 